\title{
The circular economy potential of urban organic waste streams in low- and middle-income countries
}

\author{
Daniel Ddiba ${ }^{1,2}$ (D) Kim Andersson ${ }^{2} \cdot$ Arno Rosemarin $^{2}$ (D) . \\ Helfrid Schulte-Herbrüggen ${ }^{1,3}$ (D) Sarah Dickin ${ }^{2}$ (D)
}

Received: 15 January 2020 / Accepted: 29 April 2021 / Published online: 22 May 2021

(c) The Author(s) 2021

\begin{abstract}
There is growing recognition of the potential environmental and socio-economic benefits of applying a circular approach to urban organic waste management through resource recovery. Decisions around planning and implementing circular urban waste systems require estimates of the quantity of resources available in waste streams and their potential market value. However, studies assessing circular economy potential have so-far been conducted mostly in high-income countries, yet cities in low- and middle-income countries have different challenges when developing a circular economy. This paper addresses this gap by estimating the resource recovery potential of organic waste streams in the context of low- and middle-income countries, illustrated with the case of Kampala, Uganda. A simplified material flow analysis approach is used to track the transformation of waste streams, namely faecal sludge, sewage sludge and organic solid waste into the resource recovery products biogas, solid fuel, black soldier fly larvae and compost. Findings indicate that even at current rates of waste collection, the three waste streams combined could annually yield 135,000 tonnes of solid fuel or 39.6 million $\mathrm{Nm}^{3}$ of biogas or 15,000 tonnes of black soldier fly larvae or 108,000 tonnes of compost and revenues from the products could range from 5.1 million USD from compost to 47 million USD from biogas. The results demonstrate how complex information describing urban waste can be presented to facilitate decision making and planning by stakeholders. By highlighting different resource recovery opportunities, application of this approach could provide an incentive for more sustainable urban sanitation and waste management systems.
\end{abstract}

Keywords Resource recovery - Waste reuse - Sustainable sanitation · Waste management · Faecal sludge management

Daniel Ddiba

ddiba@kth.se; daniel.ddiba@sei.org

Extended author information available on the last page of the article 


\section{Introduction}

Presently, over half of the world's population lives in cities and this proportion is expected to increase to two-thirds by 2050 , with $90 \%$ of the increase occurring in low- and middleincome countries (UN DESA, 2018). This trend implies an increasing demand for food, water and energy in cities (Hoff, 2011). At the same time, urban residents generate growing quantities of waste with over 1.6 million tonnes of organic solid waste (Kaza et al., 2018) and over 715 million $\mathrm{m}^{3}$ of municipal wastewater (Mateo-Sagasta et al., 2015) being generated daily.

Many cities in high-income countries have functioning systems for collecting and treating urban waste streams. However, the prevailing linear approach to waste management only transfers the environmental pressures downstream, e.g. through the accumulation of nutrients and micro-plastics in oceans (Boehm et al., 2017), greenhouse gas emissions from landfills (Kaza et al., 2018) and pollutant emissions from incineration (Lu et al., 2017). Meanwhile, over 700 million people in urban areas in low- and middle-income countries still lack access to improved sanitation facilities (WHO and UNICEF, 2017). In addition, they rely on unsanitary solid waste management systems, e.g. open dumpsites (Kaza et al., 2018). Overall, this results in large quantities of urban waste that are discharged into the open environment, with negative implications for human and ecosystem health. Therefore, significant investments are needed over the coming decades to address urban sanitation and waste management challenges.

However, these urban sanitation and waste management challenges also present opportunities to develop systems that emphasize resource recovery. Resource recovery from organic waste streams such as excreta and food waste is crucial because they contain nutrients, energy, water and other materials (Andersson et al., 2016), which can be recovered after treatment, hence implementing a circular economy (CE) approach to waste management. This can help to alleviate resource pressures and boost water, energy and food security in and around cities, as well as reduce risks from diseases and environmental degradation due to poor sanitation and waste management (Andersson et al., 2016). The financial benefits from resource recovery could also provide incentives for investments into improved sanitation services (Diener et al., 2014).

Kirchherr et al. (2017) described the CE as "an economic system that is based on business models which replace the 'end-of-life' concept with reducing, alternatively reusing, recycling and recovering materials in production/distribution and consumption processes ... with the aim to accomplish sustainable development". In this paper, the focus is on resource recovery from organic waste streams, a component of the CE referred to as the "biological materials cycle" (Ellen MacArthur Foundation et al., 2013). Globally, there is increasing interest in the $\mathrm{CE}$ and strategies for implementation have been developed at city, national and regional level in several countries (McDowall et al., 2017; Schröder et al., 2019). Several targets within the sustainable development goals can also contribute towards a CE (Schroeder et al., 2018).

Despite a number of potential benefits, mainstream uptake and implementation of $\mathrm{CE}$ approaches to waste management are still limited, particularly in low- and middle-income country contexts (Otoo \& Drechsel, 2018). Significant knowledge gaps exist in understanding how to scale up resource recovery, but the potential for economically justified resource recovery from urban organic waste is also not well understood (Ellen MacArthur Foundation, 2017). Previous studies on circular approaches to organic waste management within low- and middle-income countries have focused on identifying technological options (e.g. 
Lohri et al., 2017; Polprasert \& Koottatep, 2017), environmental and economic assessments (e.g. Komakech, 2014; Murray et al., 2011), social assessments (e.g. Bernstein, 2004) and business models (e.g. Otoo \& Drechsel, 2018). However, even with this available knowledge, quantitative estimates of the potential for city-wide resource recovery are rare.

Global estimates of the resource recovery potential for some waste streams and specific valorization products have been made (e.g. Schuster-Wallace et al., 2015; Trimmer et al., 2017). However, the actual recovery potential is highly context-specific and estimates can only be actionable to stakeholders if they are made at a local scale. Cities typically have a huge supply of resource-rich organic waste streams in addition to a high population that forms potential consumers of resource recovery products. This proximity of waste supply and resource recovery product demand makes cities suitable for CE implementation, especially for organic waste whereby loops can be closed locally at city scale (Zeller et al., 2019). Recent attempts have been made to generate estimates of CE potential for cities like Brussels (Zeller et al., 2019) and London (Villarroel Walker et al., 2014), but these generally focused on the quantity of waste available for resource recovery, not the quantities of products or resources that can be obtained. In low- and middle-income countries, existing studies that have explored resource recovery at city scale have focused on one specific waste stream, e.g. Diener et al. (2014).

The aim of this paper is to demonstrate how the CE valorization potential of various organic waste streams in urban areas in low- and middle-income countries can be determined. Through a case study of the city of Kampala (Uganda), the approach is demonstrated by identifying and quantifying the major available organic waste streams and potential resource recovery products. The valorization potential is quantified based on the physical and chemical characteristics of the waste streams, using an approach that can be applied to other cities in low- and middle-income countries. The structure of this paper is as follows: Sect. 2 of the paper provides an overview of the case study, while Sect. 3 describes the quantification approach and the data used in the study. Section 4 presents the results from the case study, while Sect. 5 discusses how the insights generated can inform urban organic waste and resource management practices in Kampala and also demonstrate applicability for other cities, particularly in low- and middle-income contexts. Overall conclusions are provided in Sect. 6.

\section{Case study description: Kampala (Uganda)}

Kampala is the capital city of Uganda and has a resident population of 1.5 million people, with annual growth of $2 \%$, although the daytime population doubles due to commuting flows (Nkurunziza et al., 2017). Of the city's households, $92.5 \%$ use on-site sanitation systems (Schöbitz et al., 2016). Throughout the city, it is estimated that between 2000 and 2500 tonnes of solid waste are generated every day and only $40 \%$ to $65 \%$ of this is collected and dumped at the only authorized landfill in the city (Kinobe, 2015; Tukahirwa \& Lukooya, 2015). The rest is dumped into the environment, often close to the areas where it is generated.

The city has two large wastewater treatment plants (WWTPs), which also receive faecal sludge (FS) from on-site sanitation technologies via cesspool trucks, and two smaller plants based on stabilization pond systems (Schöbitz et al., 2014). The wastewater treatment plants altogether receive about $19,500 \mathrm{~m}^{3}$ of sewage and $600 \mathrm{~m}^{3}$ of FS per day on average. 
Of the FS, only $43 \%$ of what is generated within Kampala and the suburbs is delivered to the WWTPs (Nkurunziza et al., 2017). The presence of a fast-growing urban population and hence increasing resource demand, along with increasing generation of waste amidst insufficient sanitation and waste management infrastructure, make Kampala an interesting case to examine the potential for circular approaches to waste and resource management.

\section{Data and methods}

\subsection{Scope of waste streams and resource recovery options}

The scope of the present study includes three waste streams and four resource recovery technological options as shown in Fig. 1. The waste streams are FS, sewage sludge (SS) and the organic fraction of municipal solid waste (OMSW), which are the most abundantly available organic waste streams in Kampala and in many other urban contexts in low- and middle-income countries. The resource recovery options are anaerobic digestion (AD), drying and densification to generate solid fuels, black soldier fly (BSF) processing to generate animal feed and fertilizer, and composting. These options were selected on the basis of being presently the most mature and commonly used technologies for resource recovery in the context of low- and middle-income countries (Lohri et al., 2017). Moreover, each of them has been implemented to some extent in Kampala and within Uganda previously (Nakato, 2018; Niwagaba et al., 2018; Schöbitz et al., 2014).

\subsection{Quantification approach}

The approach used in this paper to make quantitative estimates of the products that can be generated from each resource recovery option is based on material flow analysis (MFA), with linear relationships between the physical and chemical quality parameters of the waste streams and the potential quantities of resource recovery products. For each

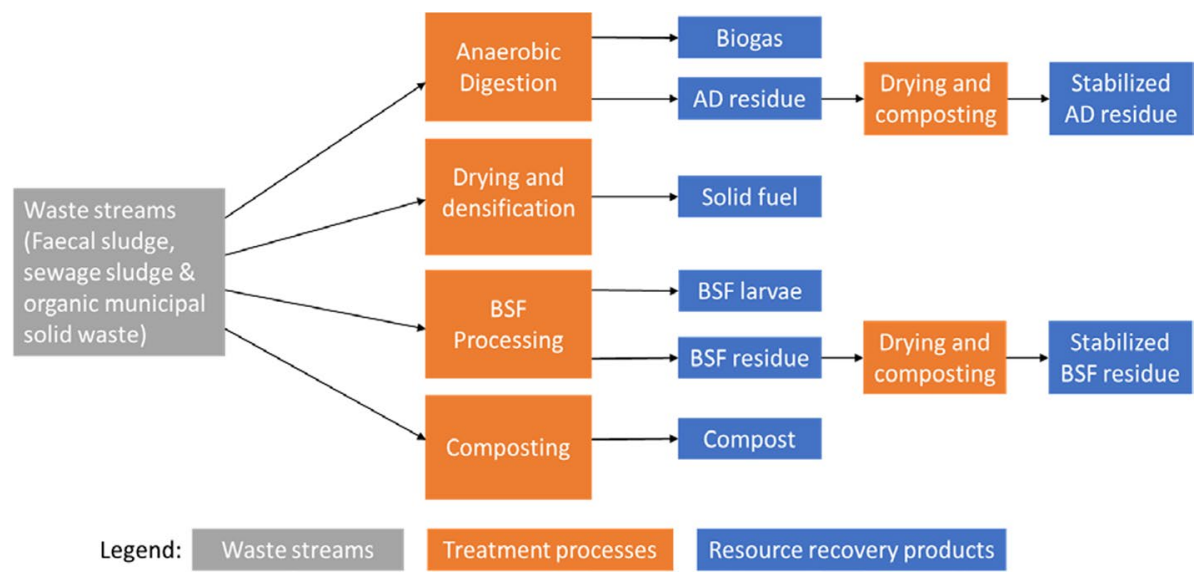

Fig. 1 Schematic representation of the waste streams and resource recovery options included in the present study 
resource recovery option, the quality parameters that determine the quantities of recoverable resources that can be obtained were identified from the literature, as described in Sects. 3.2.1-3.2.4. The mathematical relationships between these parameters and the quantity of recoverable resources and reuse products were also developed basing on available data in the literature. A framework illustrating the quantification approach is provided in Fig. 2.

While the quantity of resource recovery products that can be obtained from a particular process depends on the quality and quantity of the input waste streams as well as the operating conditions of the technological process, only the quantity and quality of the waste stream were considered in this study. This means that for a given quantity of a waste stream, the quantity of resource recovery products that can be obtained only changes with variations in the quality of that waste stream. Losses due to handling and spillage are largely dependent on the user(s), the specific construction of the technologies used and the operating conditions, not necessarily on the initial quantity of waste that is available for resource recovery. As such, detailed aspects that would ideally be covered within a feasibility study are beyond the scope of the present study. Potential revenues were calculated by multiplying the quantity of products and the estimated market prices. However, capital and operating costs for valorization facilities were not covered since they depend on contextual factors around location, size and scale among others which are beyond the scope of this study.

\subsubsection{Anaerobic digestion}

In an $\mathrm{AD}$ process, the quantity of biogas that can be generated depends on the quantity of volatile solids (VS) since this parameter represents the organic content in the feedstock (Vögeli et al., 2014). The potential biogas yield from a waste stream is typically stated as the biomethane potential (BMP) which is a measure of how much methane can be generated for each unit of VS within the feedstock (Vögeli et al., 2014).

The potential quantity of biogas $B_{v}$ in $\mathrm{Nm}^{3}$ that can be generated from $\mathrm{AD}$ is calculated using Eqs. 1 and 2. Equation 1 is applied to waste streams with quantities available in $\mathrm{m}^{3}$, while Eq. 2 is used for those in metric tonnes.

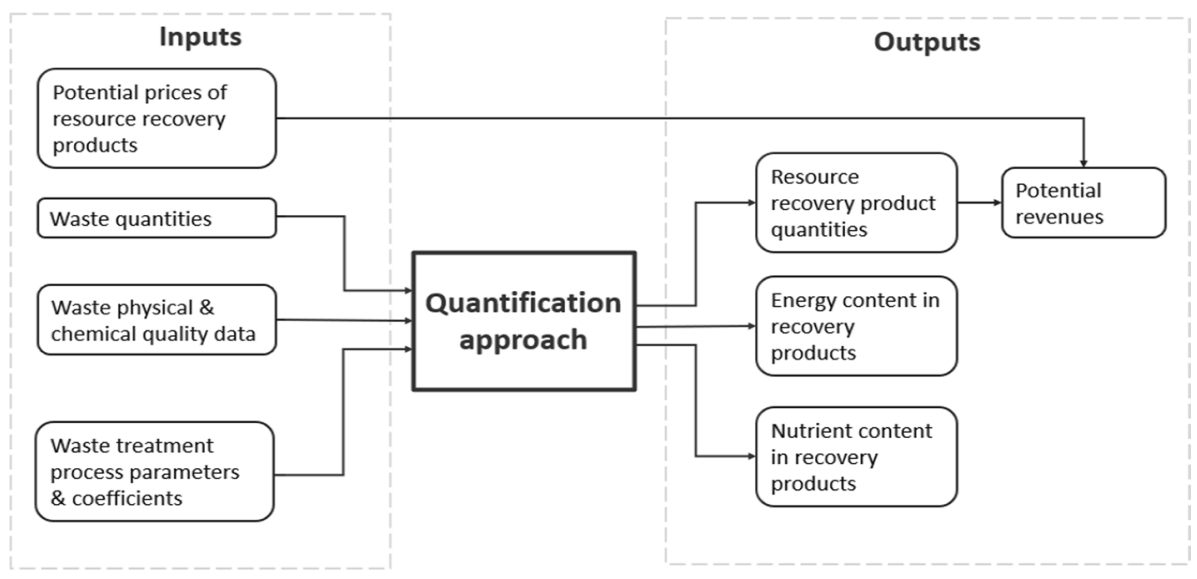

Fig. 2 Overall framework illustrating the quantification approach and the data inputs and outputs 


$$
\begin{gathered}
B_{v}=W S_{v} \times 1000 \times \frac{T S_{v}}{10^{9}} \times \frac{V S_{m}}{100} \times \frac{V S_{D}}{100} \times B M P \times \frac{100}{60} \\
B_{v}=W S_{m} \times \frac{T S_{m}}{100} \times \frac{V S_{m}}{100} \times \frac{V S_{D}}{100} \times B M P \times \frac{100}{60}
\end{gathered}
$$

$W S_{v}$ is the quantity of the waste stream in $\mathrm{m}^{3}, W S_{m}$ is the quantity of waste stream in tonnes, $T S_{v}$ is the total solids content in $\mathrm{mg} / \mathrm{L}, T S_{m}$ is the total solids content as percentage of the total wet mass, $V S_{m}$ is the quantity of volatile solids as percentage of total solids, $V S_{D}$ is the percentage rate of volatile solids degradation which indicates the fraction of VS that is biodegraded into biogas during the AD process, and BMP is the biomethane potential of the waste stream in $\mathrm{Nm}^{3} \mathrm{CH}_{4} /$ tonne VS. It was assumed that the biogas generated from the process would have a methane content of $60 \%$, which is within the typical range (Bond \& Templeton, 2011); hence, the last term of Eqs. 1 and 2 translates the quantity of methane into quantity of biogas. If the biogas is to be used as vehicle fuel, further treatment processes would be necessary, but these are not included in this study.

According to Vögeli et al. (2014), $1 \mathrm{Nm}^{3}$ of raw biogas with a methane content of $60 \%$ has an energy content of approximately $6 \mathrm{kWh}$ or $21.6 \mathrm{MJ}$. This was used to calculate the energy content in the biogas across all waste streams as shown in Eqs. 3 and 4.

$$
\text { Energy content in biogas in } \mathrm{MJ}=B_{v} \times 21.6
$$

$$
\text { Energy content in biogas in } \mathrm{kWh}=B_{v} \times 6
$$

The revenue that could be generated from the biogas is calculated using Eq. 5 .

$$
\text { Potential revenue from the biogas }=B_{v} \times B_{p}
$$

$B_{p}$ is the estimated price of biogas on the local market in US\$ $/ \mathrm{Nm}^{3}$.

Before AD residue (digestate) can be applied to agricultural land, further treatment is necessary for stabilization and pathogen reduction (Bond \& Templeton, 2011) and the assumption was made that this treatment could consist of a simplified process of drying and composting. The calculations to determine the quantity of $\mathrm{AD}$ residue that can be obtained were based on the percentage dry mass reduction $\left(\mathrm{DMR}_{\mathrm{AD}}\right)$ of the feedstock in the biogas digester. The quantity of stabilized digestate, $R_{A D}$ in DM metric tonnes, is calculated using Eq. 6 for waste stream quantities in $\mathrm{m}^{3}$ and Eq. 7 for those in metric tonnes.

$$
\begin{gathered}
R_{A D}=W S_{v} \times 1000 \times \frac{T S_{v}}{10^{9}} \times\left(1-\frac{D M R_{A D}}{100}\right) \times\left(1-\frac{D M R_{C}}{100}\right) \\
R_{A D}=W S_{m} \times \frac{T S_{m}}{100} \times\left(1-\frac{D M R_{A D}}{100}\right) \times\left(1-\frac{D M R_{C}}{100}\right)
\end{gathered}
$$

$D M R_{A D}$ is the percentage reduction of dry mass in the digestate, and $D M R_{C}$ is the percentage reduction of the dry mass of the digestate during composting for stabilization. The revenue that could be generated from the digestate is calculated using Eq. 8.

$$
\text { Potential revenue from the digestate }=R_{A D} \times C_{p}
$$


$C_{p}$ is the estimated price of products on the market that are equivalent to compost, soil amendments or soil conditioner in US\$/tonne, and $R_{A D}$ is the quantity of digestate in DM tonnes.

There is negligible nutrient removal within the AD process (Wang et al., 2010), but composting the digestate would likely result in some nutrient loss (Möller \& Müller, 2012). The nutrient content in the stabilized digestate, $N U T_{A D}$ in metric tonnes, is calculated using Eq. 9 for waste stream quantities in $\mathrm{m}^{3}$ and Eq. 10 for those in metric tonnes.

$$
\begin{aligned}
& N U T_{A D}=W S_{v} \times 1000 \times \frac{N U T_{v}}{10^{9}} \times\left(1-\frac{N R_{C}}{100}\right) \\
& N U T_{A D}=W S_{m} \times \frac{T S_{m}}{100} \times \frac{N U T_{m}}{10^{6}} \times\left(1-\frac{N R_{C}}{100}\right)
\end{aligned}
$$

$N U T_{v}$ is the concentration of the nutrient in the waste stream in $\mathrm{mg} / \mathrm{L}, N U T_{m}$ is the concentration of the nutrient in the waste stream in $\mathrm{g} / \mathrm{kg} \mathrm{TS}$, and $N R_{C}$ is the percentage nutrient mass reduction that would occur in the composting process for each of the nutrients: nitrogen $(\mathrm{N})$, phosphorus $(\mathrm{P})$ and potassium $(\mathrm{K})$. The percentage nutrient content in the digestate is calculated using Eq. 11.

$$
\text { Nutrient content in digestate }(\%)=\frac{N U T_{A D}}{R_{A D}} \times 100
$$

Equations 9, 10 and 11 were used similarly for each of the nutrients (N, P and K). The total potential revenues from $\mathrm{AD}$ as a resource recovery option were obtained by adding up the potential revenues from biogas and the digestate.

\subsubsection{Drying and densification to generate solid fuel}

To use organic waste to generate solid fuels for combustion, the key quality parameter to consider is the calorific value or heating value because this indicates the quantity of energy contained within the waste stream (Komilis et al., 2012). The quantity of solid fuel that can be obtained from a waste stream, $F_{m}$ in DM metric tonnes, is calculated using Eq. 12 for waste stream quantities in $\mathrm{m}^{3}$ and Eq. 13 for those in metric tonnes. The assumption was made that the densification process has negligible impact on the overall mass of the waste stream that is turned into fuel.

$$
\begin{gathered}
F_{m}=W S_{v} \times 1000 \times \frac{T S_{v}}{10^{9}} \\
F_{m}=W S_{m} \times \frac{T S_{m}}{100}
\end{gathered}
$$

The energy content in the fuel, $E_{F}$ in MJ, was calculated using a similar approach to that used by Diener et al. (2014). This is shown in Eq. 14 for waste stream quantities in $\mathrm{m}^{3}$ and Eq. 15 for those in metric tonnes.

$$
E_{F}=W S_{v} \times 1000 \times \frac{T S_{v}}{10^{9}} \times 1000 \times C V
$$




$$
E_{F}=W S_{m} \times \frac{T S_{m}}{100} \times 1000 \times C V
$$

$C V$ is the gross calorific value of a waste stream in MJ/kg TS. The energy content in the solid fuel was also expressed in kWh by multiplying the results from Eqs. 14 and 15 by a constant of 0.277778 which is the standard conversion from $\mathrm{MJ}$ to $\mathrm{kWh}$.

The revenue that could be obtained from the solid fuel is calculated using Eq. 16.

$$
\text { Potential revenue from the solid fuel }=F_{m} \times F_{p}
$$

$F_{p}$ is the estimated price of the solid fuel in US\$/tonne.

\subsubsection{Black soldier fly processing}

In BSF processing, the bioconversion rate (BCR) indicates the efficiency of production of BSF larvae (Banks, 2014). The BCR is the percentage ratio of the dry mass of the larvae produced to the dry mass of the waste stream they are fed on (Banks, 2014). Equation 17 is used to calculate the quantity of BSF larvae, $B S F_{m}$, in DM tonnes that can be obtained from waste streams in $\mathrm{m}^{3}$ and Eq. 18 for waste streams in metric tonnes.

$$
\begin{gathered}
B S F_{m}=W S_{v} \times 1000 \times \frac{T S_{v}}{10^{9}} \times \frac{\mathrm{BCR}}{100} \\
B S F_{m}=W S_{m} \times \frac{T S_{m}}{100} \times \frac{\mathrm{BCR}}{100}
\end{gathered}
$$

BCR is in percentage terms, and the other parameters are as described in Sects.3.2.1 and 3.2.2.

BSF larvae contain approximately $40 \%$ protein and $30 \%$ fat (Diener, 2010), so the protein and fat content in the quantities of BSF larvae are calculated using Eq. 19 and Eq. 20, respectively:

$$
\text { Protein content in the BSF larvae (tonnes) }=B S F_{m} \times 0.4
$$

$$
\text { Fat content in the BSF larvae (tonnes) }=B S F_{m} \times 0.3
$$

Some studies have shown that the fat in BSF larvae can be used to make biodiesel (Nguyen et al., 2018), even though there are no full-scale applications so far to the best of the authors' knowledge and the economic feasibility at industrial scale is yet to be proven (Surendra et al., 2020). Therefore, the use of BSF larvae for biofuel production and energy recovery was not explored in this study. The revenues that could be generated from the BSF larvae are calculated using Eq. 21.

$$
\text { Potential revenues from BSF larvae }=B S F_{m} \times B S F_{p}
$$

$B S F_{p}$ is the estimated price of the BSF larvae in US\$/tonne on the market.

The residue from BSF processing typically requires further treatment for stabilization (Diener, 2010), and the assumption was made that this treatment could consist of a simplified process of drying and composting. Therefore, the calculation to determine the quantity of stabilized residue from the BSF treatment took into account the DM reduction due to 
bioconversion by BSF larvae as well as a further DM reduction during composting. Equation 22 is used for waste stream quantities in $\mathrm{m}^{3}$ and Eq. 23 for those in metric tonnes.

$$
\begin{gathered}
R_{B S F}=W S_{v} \times 1000 \times \frac{T S_{v}}{10^{9}} \times\left(1-\frac{D M R_{B S F}}{100}\right) \times\left(1-\frac{D M R_{C}}{100}\right) \\
R_{B S F}=W S_{m} \times \frac{T S_{m}}{100} \times\left(1-\frac{D M R_{B S F}}{100}\right) \times\left(1-\frac{D M R_{C}}{100}\right)
\end{gathered}
$$

$R_{B S F}$ is the quantity of stabilized BSF residue in DM metric tonnes, $D M R_{B S F}$ is the percentage DM reduction in the BSF process, and $D M R_{C}$ is the percentage DM reduction of the $\mathrm{BSF}$ residue due to composting.

The revenues that could be generated from the residue after BSF processing and stabilization are calculated using Eq. 24.

$$
\text { Potential revenue from BSF residue }=R_{B S F} \times C_{p}
$$

$C_{p}$ is the estimated price of products equivalent to soil amendments or compost on the market in US\$/tonne.

BSF processing results in a significant nutrient reduction in the residue (Van Huis et al., 2013). This was taken into account during the calculation for the nutrient content in the residue, including any nutrient losses that occur due to the subsequent composting process. To determine the nutrient content in the BSF residue, Eq. 25 is used for waste stream quantities in $\mathrm{m}^{3}$ and Eq. 26 for waste streams in metric tonnes.

$$
\begin{aligned}
& N U T_{B S F}=W S_{v} \times 1000 \times \frac{N U T_{v}}{10^{9}} \times\left(1-\frac{N R_{B S F}}{100}\right) \times\left(1-\frac{N R_{C}}{100}\right) \\
& N U T_{B S F}=W S_{m} \times \frac{T S_{m}}{100} \times \frac{N U T_{m}}{10^{6}} \times\left(1-\frac{N R_{B S F}}{100}\right) \times\left(1-\frac{N R_{C}}{100}\right)
\end{aligned}
$$

$N U T_{B S F}$ is the quantity of each nutrient in the BSF residue in DM metric tonnes, $N R_{B S F}$ is the percentage reduction of nutrients that occurs during the BSF process for each of the nutrients, and $N R_{C}$ is the percentage nutrient mass reduction that occurs during composting for each of the nutrients. The percentage nutrient content was calculated using Eq. 27.

$$
\text { Nutrient content in BSF residue }(\%)=\frac{N U T_{B S F}}{R_{B S F}} \times 100
$$

Equations 25, 26 and 27 are used similarly for each of the nutrients (N, P \& K).

\subsubsection{Composting}

For compost, the key factors to consider are the moisture and nutrient content. The moisture content is important because too much moisture creates anoxic and anaerobic zones, potentially leading to bad odours, while too little moisture can inhibit microbial activity which is necessary for the process to occur (Liang et al., 2003). Therefore, the quantity of compost that can be obtained, $C_{m}$ in DM metric tonnes, is calculated using Eq. 28 for waste stream quantities in $\mathrm{m}^{3}$ and Eq. 29 for those in metric tonnes. 


$$
\begin{gathered}
C_{m}=W S_{v} \times 1000 \times \frac{T S_{v}}{10^{9}} \times\left(1-\frac{D M R_{C}}{100}\right) \\
C_{m}=W S_{m} \times \frac{T S_{m}}{100} \times\left(1-\frac{D M R_{C}}{100}\right)
\end{gathered}
$$

$D M R_{C}$ is the percentage reduction in DM of the waste stream as a result of the composting process. The revenue that could be generated from the compost is calculated using Eq. 30 .

$$
\text { Potential revenue from compost }=C_{m} \times C_{p}
$$

$C_{p}$ is the price of compost in US\$/tonne.

During the composting process, some of the nutrients are lost due to volatilization and leaching and this influences the nutrient value of the resulting compost (Sommer, 2001). The nutrient content in the compost, $N U T_{C}$ in DM metric tonnes, was calculated in the same way as $N U T_{A D}$ using Eqs. 9 and 10 since the nutrient content in both cases was assumed to be only affected by the composting process for stabilization. The percentage nutrient content is calculated using Eq. 31

$$
\text { Nutrient content in the compost }(\%)=\frac{N U T_{C}}{C_{m}} \times 100
$$

$N U T_{C}$ is the quantity of each nutrient in the compost in tonnes. Equation 31 is used in the same way for each of the three major nutrients (N, P and K).

\subsection{Data used for the quantification}

The waste stream quantities used in this study are indicated in Table 1. Two scenarios were analyzed: one focusing on the quantities of waste currently collected in the city (scenario 1) and another focusing on the quantities of waste that could be collected if the waste collection infrastructure and logistics had a wider coverage and higher efficiency (scenario 2). The physical and chemical quality parameters of the waste streams are shown in Table 2, while data on parameters related to the treatment and resource recovery processes are shown in Table 3. The price data that were used to estimate the potential revenues from resource recovery products are shown in Table 4. Details on how the data in Tables 1 and 4 were derived are provided in Supplementary Information (SI). The equations and data for the two scenarios were put in spreadsheets (all available at https://doi.org/10.5281/zenodo. 4452199) to facilitate ease of calculations.

Table 1 Quantities of waste streams in Kampala

\begin{tabular}{lllll}
\hline Waste stream & Units & $\begin{array}{l}\text { Current waste collec- } \\
\text { tion (scenario 1) }\end{array}$ & $\begin{array}{l}\text { Potential waste collec- } \\
\text { tion (scenario 2) }\end{array}$ & References \\
\hline Faecal sludge & m $^{3}$ /year & 219,000 & 509,175 & SI - section A.1.1 \\
Sewage sludge & tonnes/year & 31,317 & 92,345 & SI - section A.1.2 \\
$\begin{array}{l}\text { Organic municipal } \\
\text { solid waste }\end{array}$ & tonnes/year & 436,540 & 671,600 & SI - section A.1.3 \\
\hline
\end{tabular}

Note $\mathrm{SI}=$ Supplementary Information 

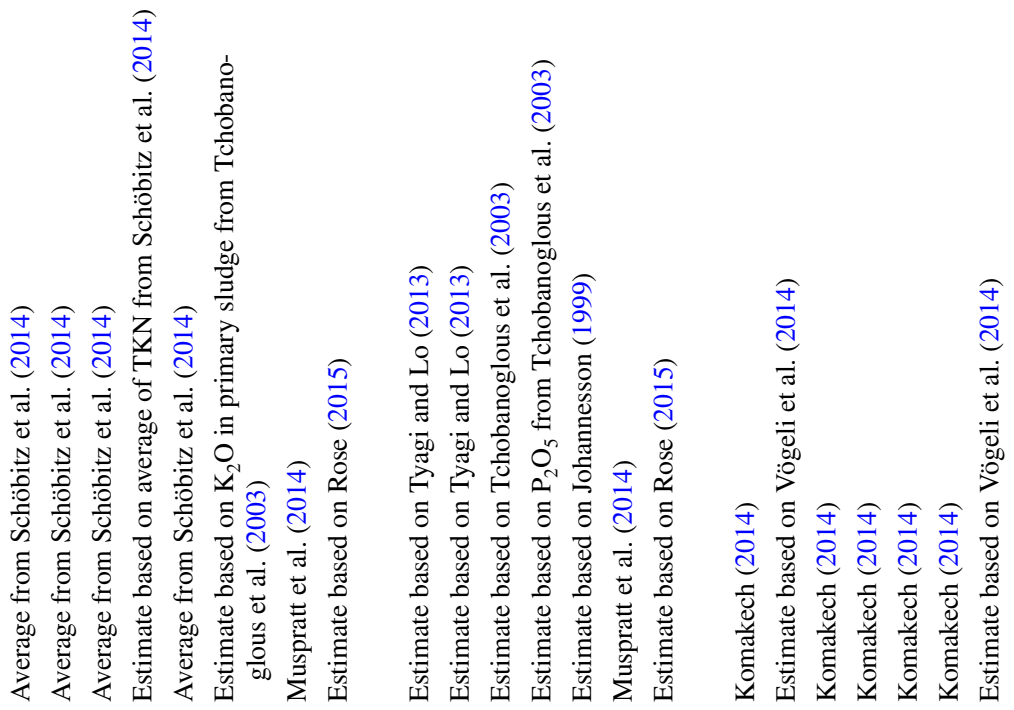

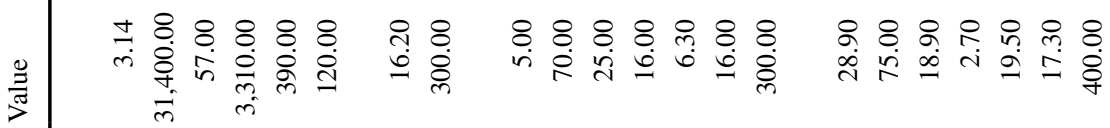

:

䨔

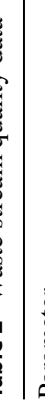

$>\sum_{\infty}^{q}$

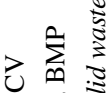

$\frac{\sqrt{2}}{3}$

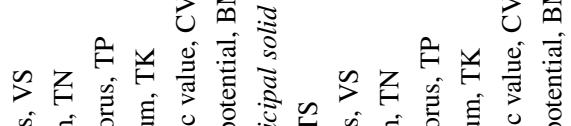

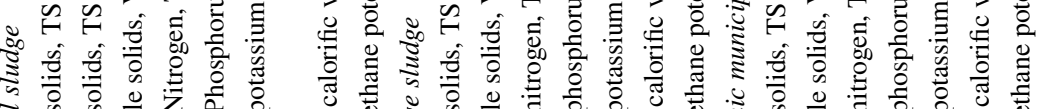
б

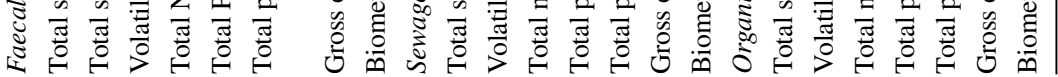




\section{Results}

A summary of the overall CE potential from organic waste streams in Kampala is presented in Table 5. The findings indicate that with increased waste collection (Scenario 2), up to 62.5 million $\mathrm{Nm}^{3}$ of biogas could be obtained along with 56,000 tonnes of digestate, from AD. If all the waste streams were instead dried and densified, up to 215,000 tonnes of solid fuel could be obtained. If all the waste streams were used for breeding BSF larvae, up to 24,000 tonnes of BSF larvae could be generated along with 56,000 tonnes of BSF residue. The potential annual revenues from these products could range from US\$ 5.1 million from compost under Scenario 1 to US\$ 77 million from AD under Scenario 2.

The graphs in Fig. 3 also indicate that significant quantities of nutrient recovery products could be obtained in both scenarios from composting, the BSF process and AD. In both scenarios however, the quantities of nutrients that can be recovered from FS are significantly higher than the recoverable quantities from OMSW and SS. The nutrient recovery products from SS have the order of a few kilograms of each nutrient, while those from FS has the order of hundreds of tonnes. Comparing between resource recovery options, the quantity of nutrients that can be recovered from digestate and from composting seems similar, while a much lower quantity of nutrients can be recovered from the residue of BSF processing. Figure 3 also indicates that nitrogen is the dominant nutrient within the recovery products from $\mathrm{AD}$, composting and BSF breeding, except for OMSW where potassium is the dominant one.

With regard to energy recovery, Fig. 4 indicates that more energy can be recovered in products from OMSW than from FS or SS. The quantity of energy that can be recovered in the form of solid fuel products is also shown to be higher than the energy that can be recovered in the form of biogas. This results in higher revenues from solid fuel in the case of FS and SS as shown in Fig. 5, in contrast with OMSW where the revenues from AD are higher. Figure 5 also illustrates that more significant revenues can be generated through resource recovery from OMSW in comparison with FS and SS. In Table 5, it can be seen that the annual revenue potential from nutrient recovery products in Kampala ranges from US\$ 1.6 million for the residue from BSF breeding within Scenario 1 to US\$ 8.1 million for compost within Scenario 2. This is significantly lower than the potential revenues from solid fuel or biogas in both scenarios.

Detailed tables with the disaggregated results for both scenarios are provided in Supplementary Information.

\section{Discussion}

\subsection{Recovery of energy}

The results indicate that more energy could be recovered by converting the waste streams into solid fuel, in contrast to anaerobic digestion. This reflects the gross calorific value in the waste streams which ranges from 16.2 MJ/Kg TS for FS (Muspratt et al., 2014) to 17.3 MJ/Kg TS for OMSW (Komakech, 2014) in comparison with the energy content in biogas which is $21.6 \mathrm{MJ} / \mathrm{m}^{3}$ (Vögeli et al., 2014). The relatively higher potential revenues from anaerobic digestion of OMSW could be explained by the higher biomethane potential and volatile solids content of the OMSW in comparison with the FS and SS which lead to 


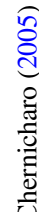

它

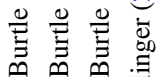

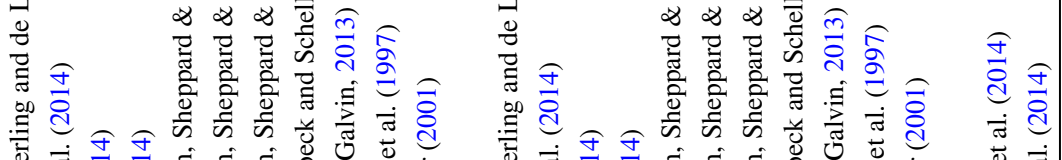

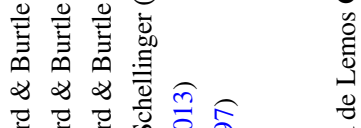

๙ิ่

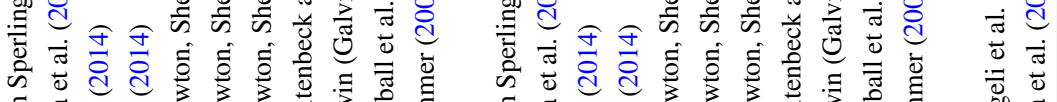

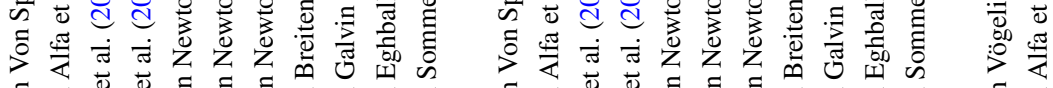
ప

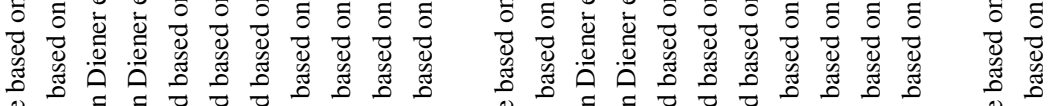

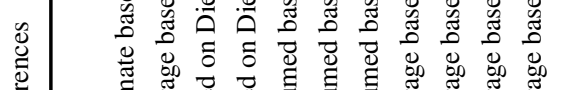

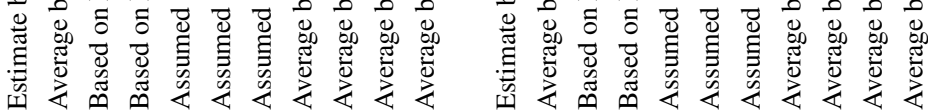
ก :

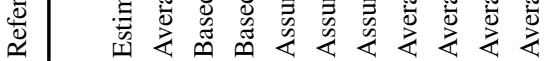
《

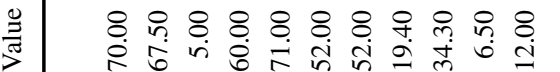

\& 유 \& \& \& \& 우요 \& \& 은

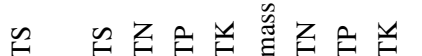

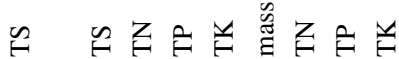

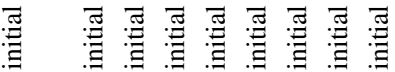

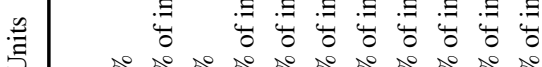

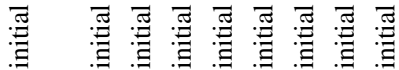

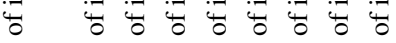

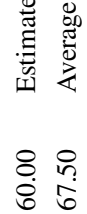

$\sum^{\gtrless}$

今ิ

원

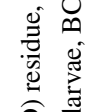

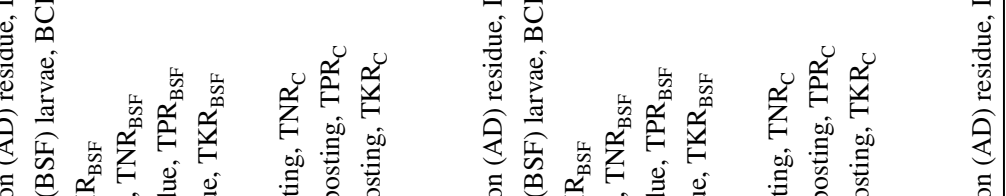

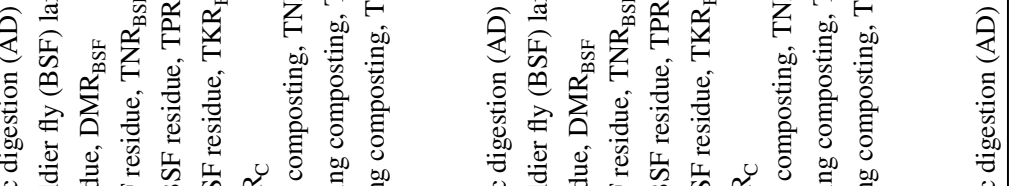

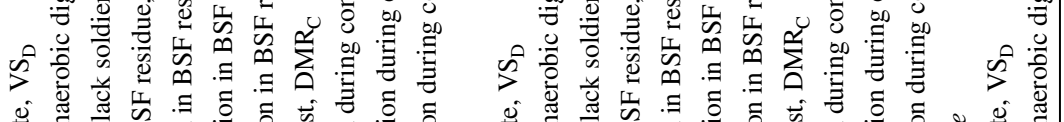

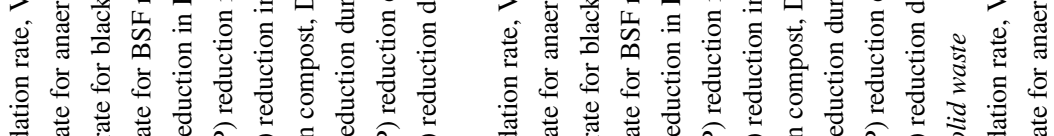

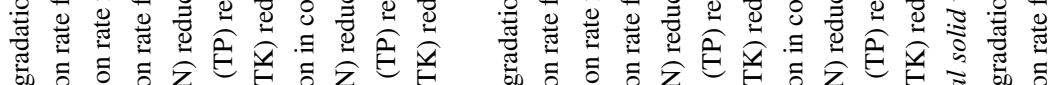

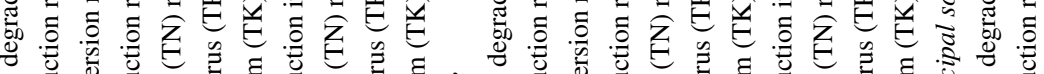

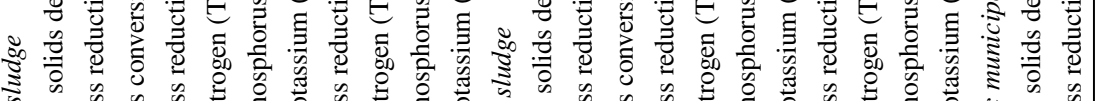

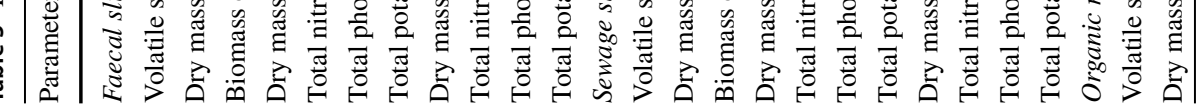




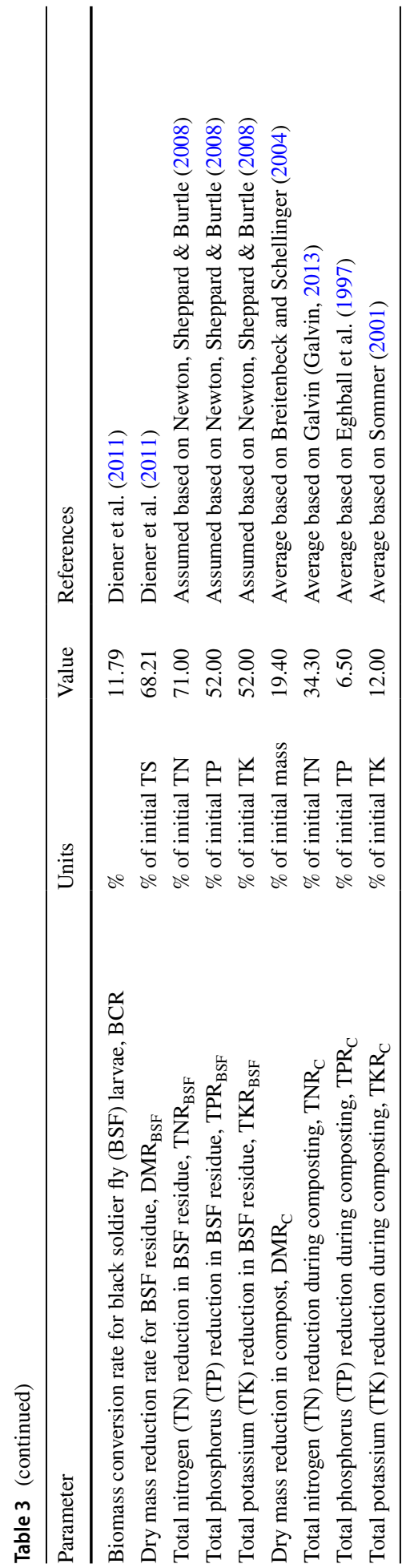


Table 4 Estimated prices of resource recovery products in Kampala

\begin{tabular}{lcll}
\hline Resource recovery product & Estimated price & Units & References \\
\hline Biogas & 1.19 & US $\$ / \mathrm{Nm}^{3}$ & SI-section A.2.1 \\
Solid fuel & 333.33 & US $\$$ tonne & SI-section A.2.2 \\
Black soldier fly larvae & 810.00 & US $\$$ tonne & SI—section A.2.3 \\
Compost & 47.00 & US $\$$ tonne & SI—section A.2.4 \\
\hline
\end{tabular}

Note $\mathrm{SI}=$ Supplementary information

higher biogas yields and hence higher revenues. OMSW often largely consists of fruit and vegetable waste which tend to have a higher carbon/nitrogen ratio which is associated with better biogas yields (Müller, 2009). Therefore, in instances where optimizing biogas yields is the goal, the waste streams may have to be mixed as suggested by Minale and Worku (2014).

While biogas from AD has been used extensively for heat and power and as a vehicle fuel in high-income countries, the applications in low- and middle-income countries have mainly been in the form of fuel for cooking and to some limited extent, generating electricity (Otoo \& Drechsel, 2018). Similarly, solid fuels in the form of briquettes and pellets have been largely used as fuel for cooking, although there is interest in industrial applications (Gold et al., 2017). In a global review, Trimmer et al. (2017) suggested that energy recovery from sanitation could have limited potential impact on overall energy use. However, that is because their analysis relied on electricity use data yet the reality is that in lowand middle-income countries, household energy use is often in forms other than electricity (Njenga \& Mendum, 2018).

Across the globe, there is increasing interest in alternative renewable sources of energy (Otoo \& Drechsel, 2018). Like much of the rest of Sub-Saharan Africa where 90-100\% of the household energy demand is for cooking and $75 \%$ of that is from firewood (Smith et al., 2011), 78\% of Kampala's population relies on woody biomass for cooking fuel, with each person consuming an average of $240 \mathrm{~kg}$ of firewood and $120 \mathrm{~kg}$ of charcoal annually (MEMD, 2012). Firewood has a gross calorific value of $16 \mathrm{MJ} / \mathrm{kg}$, while that for charcoal is $28 \mathrm{MJ} / \mathrm{kg}$ (Diener et al., 2014). Given Kampala's resident population of 1.5 million, this implies that the total consumption of energy from firewood in the city is $5.76 \mathrm{PJ}$ and that from charcoal is 5.04 PJ annually, hence a total of $10.8 \mathrm{PJ}$ from both sources. Valorization of solid fuel from Kampala's organic waste could generate $2.32 \mathrm{PJ}$ of energy in scenario 1 and 3.69 PJ in scenario 2, hence demonstrating the potential to substitute for $22 \%$ to $34 \%$ of Kampala's current wood-based fuel consumption. This demonstrates the potential impact of energy recovery from organic waste and the potential contribution to progress towards sustainable development goal (SDG) 7 - affordable and clean energy, as well as the environmental benefits from reduced reliance on woody biomass for fuel (Otoo \& Drechsel, 2018). 


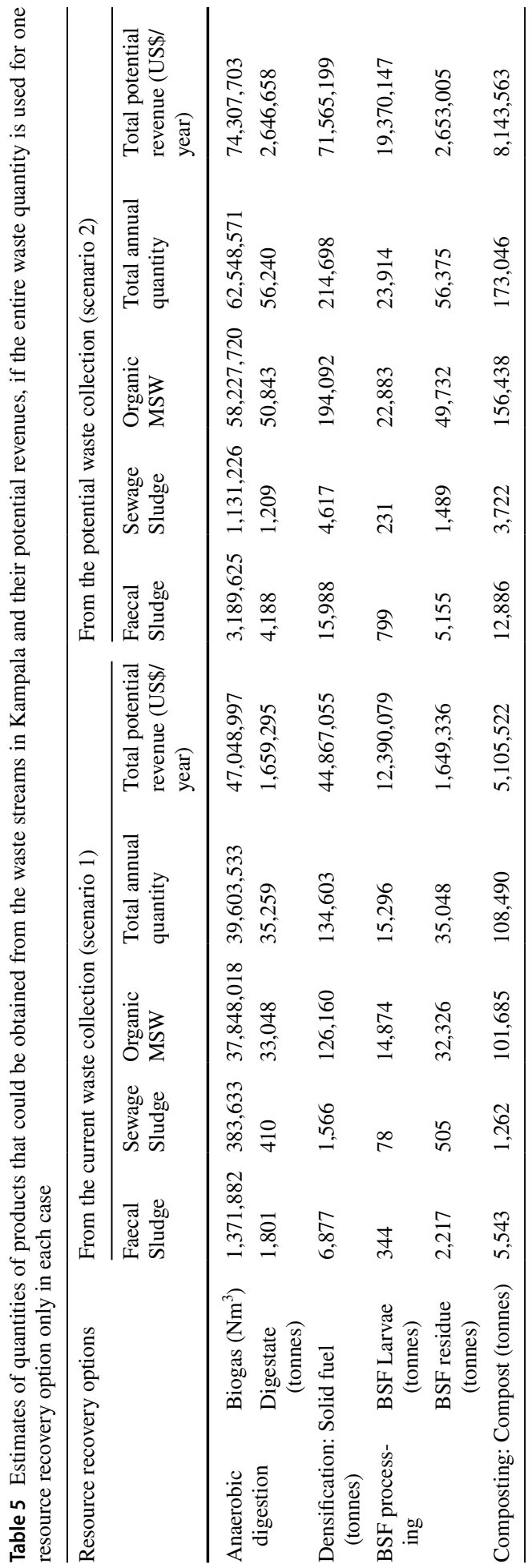



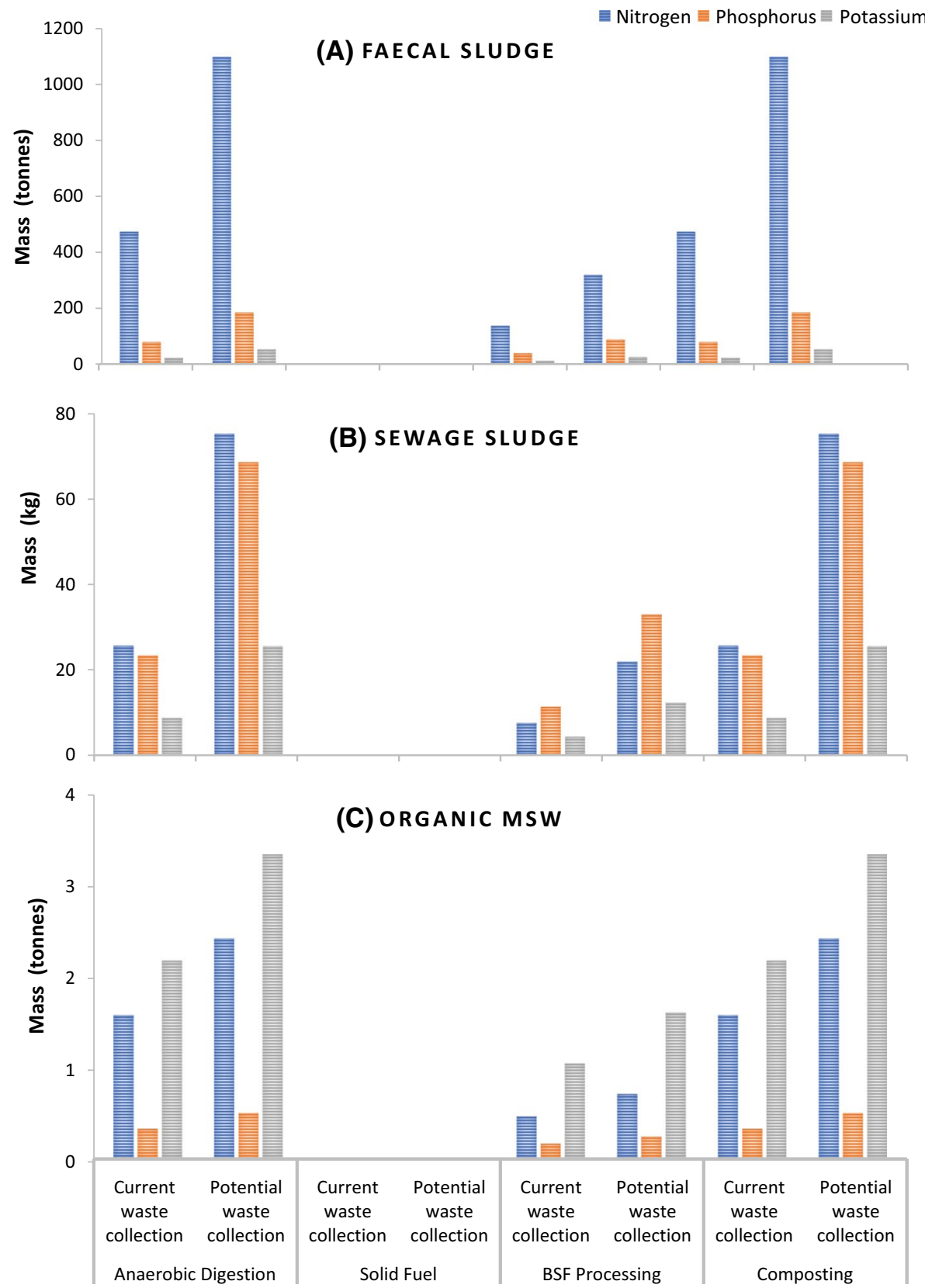

Fig. 3 Comparison of the four resource recovery options in both scenarios based on the total nutrient quantities in resource recovery products that can be generated from faecal sludge (A), sewage sludge (B) and organic MSW (C) in Kampala annually 

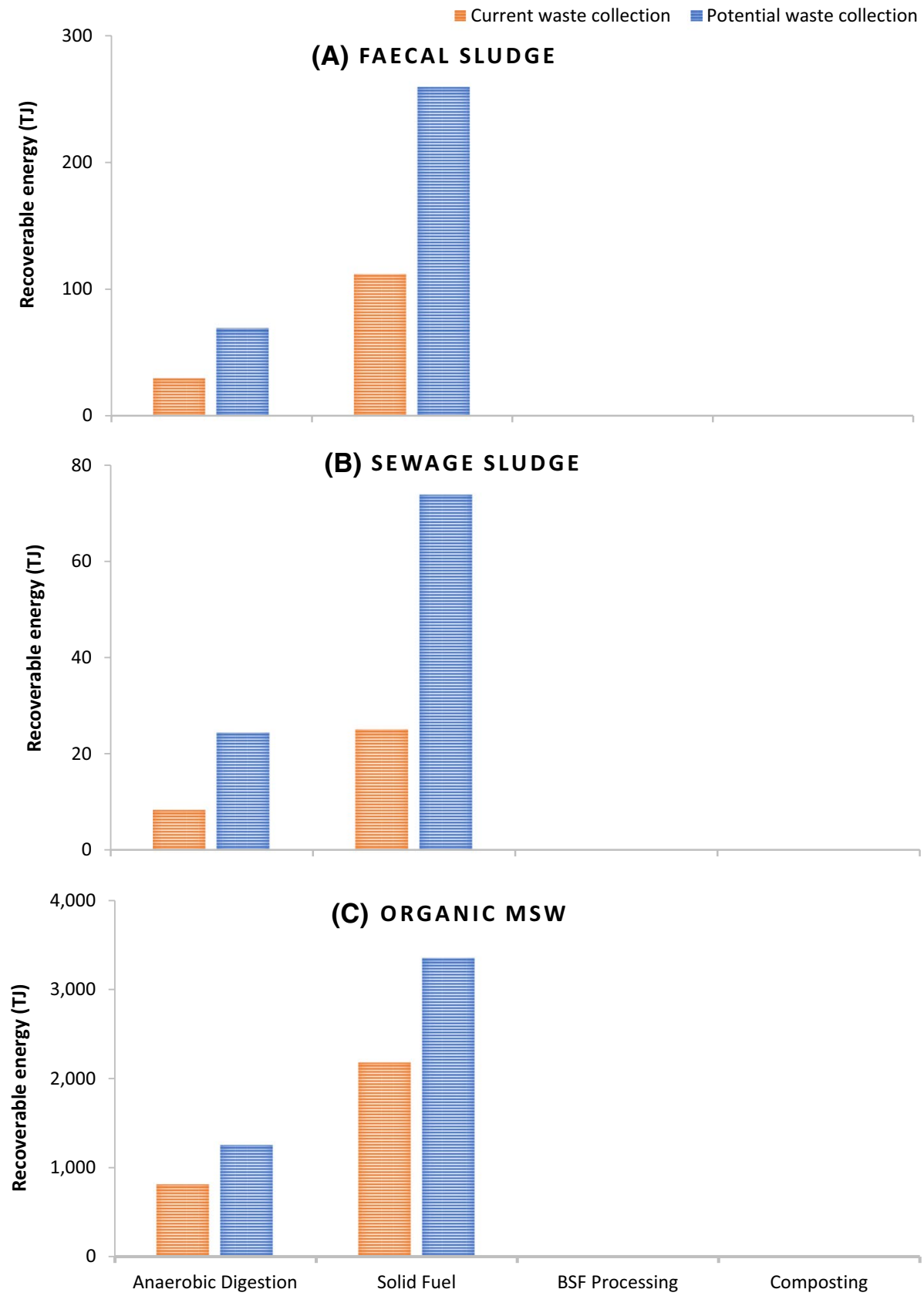

Fig. 4 Comparison of the four resource recovery options in both scenarios based on the total energy content in resource recovery products that can be generated from faecal sludge (A), sewage sludge (B) and organic $\operatorname{MSW}(\mathbf{C})$ in Kampala annually 

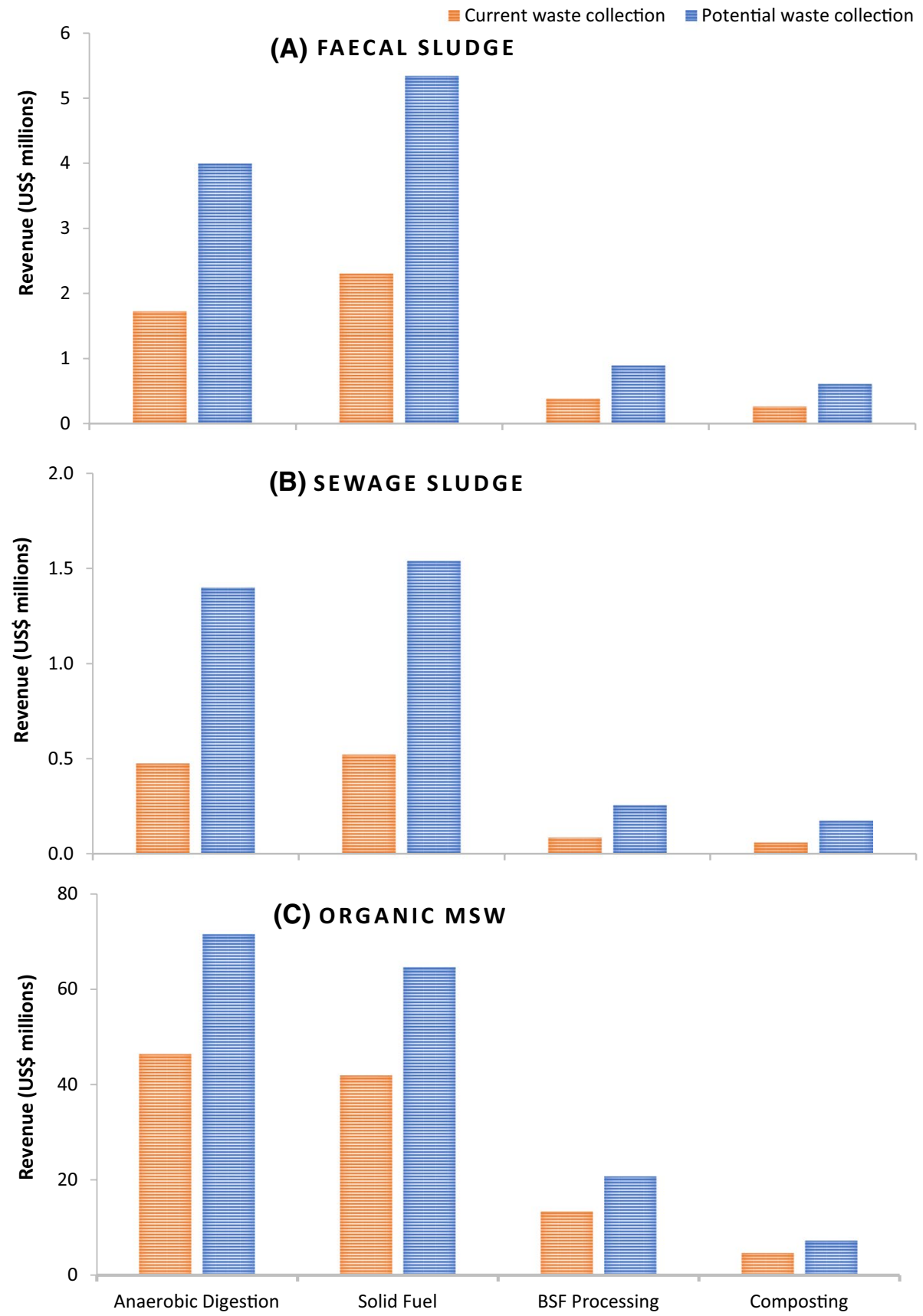

Fig. 5 Comparison of the four resource recovery options in both scenarios based on the total potential revenues from resource recovery products that can be generated from faecal sludge (A), sewage sludge (B) and organic MSW (C) in Kampala annually 


\subsection{Recovery of nutrients}

As seen from Fig. 3, the variation in the quantity of nutrients that can be recovered in each valorization option reflects the nutrient content in the raw waste streams, and the varying extents to which nutrients remain in the residue while undergoing $\mathrm{AD}$, composting and BSF breeding processes. These factors underscore the need for waste characterization efforts both before implementing and regularly throughout the operation of any resource recovery initiative, especially in contexts where nutrient recovery is the aim.

In Fig. 3, it can be seen that the levels of nutrient recovery from $\mathrm{AD}$ and composting are similar. This is attributed to the assumption that digestate would go through a composting process for stabilization before being used on agricultural land. It is not unusual for digestate to be stabilized through composting, but the process would result in some nutrient loss just like any typical composting process of raw waste streams (Möller \& Müller, 2012).

The results indicate that higher quantities of nutrients can be recovered from FS, in comparison with SS and OMSW in both scenarios. Therefore, if waste streams were to be treated separately, the focus of FS valorization should be for nutrient recovery. An alternative approach for optimizing nutrient recovery would be to combine the waste streams since FS and SS have relatively higher proportions of nitrogen, while OMSW has a relatively higher proportion of potassium. The advantages of this approach have been documented, e.g. from co-composting FS and OMSW (Cofie et al., 2009), and there are some full-scale implementations in Africa and Asia (Otoo \& Drechsel, 2018).

The results also indicate that the annual revenue potential from nutrient recovery products in Kampala is significantly lower than from solid fuel or biogas in both scenarios. This is in line with findings from previous studies in low- and middle-income countries which have shown that for FS for example, the highest financial value from resource recovery would be obtained by valorization for energy (Diener et al., 2014). Nutrient recovery in the form of compost or soil conditioner tends to have a lower financial value because farmers who are the target market have concerns about low nutrient content, perceived and real health risks associated with excreta-derived products and the difficulty of handling on the farm in comparison with chemical fertilizers (Danso et al., 2017). In some cities in sub-Saharan Africa, the price that farmers are willing to pay for compost would be insufficient to even cover the costs associated with the waste treatment processes (Strande et al., 2014). Potential approaches to mitigate this low uptake of nutrient products have focused on, e.g. fortification, putting waste-derived compost in appealing packages and certification schemes (Danso et al., 2017; Otoo \& Drechsel, 2018), and some of these efforts have resulted in higher prices being paid for excreta-derived fertilizers, e.g. in Haiti and Kenya (Moya et al., 2019).

\subsection{Fly larvae production}

In recent years, there has been erratic supply along with price fluctuations for the traditional sources of protein in animal feed, e.g. fish meal and soybeans in Uganda (Onen et al., 2019). Since BSF larvae can be bred on a wide range of organic waste streams which are abundantly available in typical urban settings, they are seen as viable alternative ingredients for animal feed within livestock enterprises (Joly \& Nikiema, 2019). Fly larvae production therefore forms another option for nutrient recovery through turning organic waste into animal feed. 
Diener et al. (2014) estimated that the potential market value of BSF larvae from collected FS in Kampala could be US\$ 109,200/year. This is much less than the estimate of US\$278,500/year within scenario 1 in the present study. The difference is because Diener et al. (2014) estimated the value of BSF larvae based on the price of an equivalent quantity of protein in fish meal, while the present study is based on reported prices of BSF larvae from existing operations in Uganda (see Supplementary Information).

Besides breeding BSF larvae, there are other approaches for valorizing organic waste streams using insect larvae (St-Hilaire et al., 2007) and worms (Lohri et al., 2017). These approaches also have potential for making animal feed. However, BSF larvae seems to have gained relatively more interest in recent years for commercial-scale applications (Lohri et al., 2017). There are pilot and full-scale facilities producing BSF larvae from a range of organic waste streams in low- and middle-income countries like Uganda (Nakato, 2018), Kenya (Moya et al., 2019), South Africa, Ghana and Indonesia as well as in high-income countries like USA, Canada and the Netherlands (Joly \& Nikiema, 2019).

In Kampala, one of the major ingredients for animal feed is dried fish, whose protein content is $60 \%$ (Sauvant et al., 2004). Farmers usually mix this with other substances like maize bran to make feeds for chicken, pigs, cattle and other livestock. BSF larvae has a protein content of $40 \%$, and hence, 1 tonne of dried fish could be substituted by 1.5 tonnes of BSF larvae. This implies that the quantity of BSF larvae that can be produced from organic waste streams in Kampala could substitute for between 10,000 and 16,000 tonnes of dried fish. There is increasing demand for animal-based protein in people's diet, especially in low- and middle-income countries (Boland et al., 2013), which in turn drives demand for animal feed ingredients. Having BSF larvae as a substitute for fish meal within animal feed ingredients could therefore mitigate some of the impact from the demand for animal-based protein on fish stocks and other marine resources (Van Huis et al., 2013) and hence contribute to progress towards SDG target 14.4 which is about ending overfishing and illegal fishing practices so as to restore fish stocks.

BSF larvae also has significant potential for effective waste treatment considering that the waste quantities can be reduced by 50 to $80 \%$ (Lohri et al., 2017), while having relatively low greenhouse gas emissions (Ermolaev et al., 2019). Recent studies have also demonstrated the impact of BSF larvae activity on reducing pathogens like Salmonella spp. as well as some pharmaceuticals and pesticides (Lalander et al., , 2013, 2016).

\subsection{Implications for sanitation, waste and resource management}

The results from this study show that there is great potential to generate value through resource recovery from organic waste streams in Kampala, especially from OMSW which is currently collected in significantly higher quantities than FS or SS. This signals the need for further investments in the infrastructure for collecting FS and SS. The insights revealed hereby could enable urban decision-makers to embark on a paradigm shift from waste treatment for disposal to waste treatment for resource recovery, and it could encourage investments in sustainable waste and resource management which could address the challenge of growing urban populations and the consequent energy, food and water demands (Andersson et al., 2016; Rao et al., 2015).

From a policy and practice perspective, this analysis could be useful as a first step to enable city authorities and planners to understand the impact that resource recovery could have on resource consumption in a city. In Kampala where most of the solid waste that is collected ends up at a landfill, Komakech (2014) showed that the quantity of nutrients 
disposed of annually at the landfill was equivalent to about $92 \%, 110 \%$ and $680 \%$, respectively, of the nitrogen, phosphorus and potassium imported to Uganda annually as chemical fertilizers. This therefore highlights the extent to which nutrient recovery from organic waste streams could reduce the dependence on chemical fertilizers.

Other products that could be substituted with considerable positive environmental and socio-economic impacts include dried fish meal for animal feeds and imported fertilizers (Diener et al., 2014; Otoo \& Drechsel, 2018). Additional benefits include cost savings, depending on the resource recovery option, since waste would only need to be treated to standards appropriate for the intended end-use and not to the rigorous standards for discharging into recipient waters or other vital ecosystems, as currently demanded (Otoo \& Drechsel, 2018). Moreover, analysis by Schroeder et al. (2018) has shown that $\mathrm{CE}$ initiatives can contribute directly to achieving several targets of the sustainable development goals (SDGs), especially SDG6 - clean water and sanitation, SDG7-affordable and clean energy, SDG 8-decent work and economic growth, SDG 12-responsible consumption and production and SDG 15-life on land. This therefore demonstrates the impact that $\mathrm{CE}$ valorization from organic waste can have in a development context.

Realizing the valorization potential highlighted by this study does not imply that waste treatment must be carried out on a large scale at centralized facilities. It may be feasible to establish several decentralized facilities in a city or to promote resource recovery practices and technologies at household or neighbourhood levels, depending on what business models and logistic arrangements are viable (Otoo \& Drechsel, 2018). Indeed, the challenges of creating efficient and effective logistic systems for the management of urban waste streams are the subject of an increasing number of studies, including Kinobe (2015) and Schöbitz et al., (2017). Thus, the information generated in this study can provide relevant information to guide planning in such contexts. Operationalizing the information produced in this study would therefore require going beyond revenues and determining the capital and operating costs for various treatment technologies at different scales as well as the existing demand for various resource recovery products to determine those most feasible for Kampala. The feasibility of increasing the coverage and efficiency of collection systems for the various waste streams would also have to be determined since several technical, institutional and socio-economic factors may influence the extent to which collection rates can be improved.

At the same time, different resource recovery options could imply trade-offs between aspects such as nutrient recovery and energy recovery as the comparisons in Figs. 2, 3 illustrate. There are multiple valorization options for each organic waste stream (Lohri et al., 2017), and addressing this potential competition for feedstock could perhaps require earmarking different waste streams for different valorization options depending on what is most suitable, as discussed in Sect. 5.2 for FS and nutrient recovery. The valorization options are also associated with different types of environmental challenges. For example, AD could lead to leakage of methane, while combustion of solid fuels could lead to air pollutants. However, other environmental impacts are avoided, for example nutrient enrichment from effluents to surface water bodies. For a more detailed evaluation, more comprehensive tools, e.g. life cycle assessment, are needed. Nevertheless, the approach in this study could inform decision-support tools for stakeholders to be able to easily compare resource recovery options as there is a gap in such tools for LMICs (Ddiba, 2020).

For cities like Kampala, the simplicity of the approach used in this study could also enable participatory dialogues with stakeholders from a wide range of sectors and backgrounds including sanitation, waste management, energy, agriculture, water, health and 
environment, among others. The collaboration of multiple stakeholders is necessary to enable resource recovery to happen (Otoo \& Drechsel, 2018), and the results from this analysis can provide a starting point for such collaboration, in Kampala and other cities in low- and middle-income countries with similar contexts.

\subsection{Limitations}

From a scientific perspective, conducting this analysis for Kampala highlights a number of future opportunities to apply a similar approach for decision support around CE potential in other urban contexts, as well as current limitations. The present study focused on only three waste streams, but other flows of organic waste in urban areas, e.g. animal manure, agricultural residues and food industry by-products, could be covered if data were available on their quantities and characteristics. This therefore presents an area for further research, as well as investigating other valorization options as new technologies mature.

Since the results were largely influenced by the quality of the various waste streams, it is crucial to examine the data that are utilized. The physical and chemical characteristics of waste streams vary across time and sources, as has been acknowledged by e.g. Strande et al. (2018) and Komakech (2014). For example, the concentration of TS in FS could range from 12,000 to 52,500 mg/L (Strande et al., 2014), while the nutrient content in OMSW in Kampala is reported as varying between wet and dry seasons (Komakech, 2014). This therefore demonstrates the need for detailed waste characterization as part of the feasibility assessment process for any valorization initiative.

This study provided estimates of the potential for resource recovery from Kampala's organic waste streams, based on the quantity and quality of waste streams. However, since organic waste stream generation, treatment and resource recovery can take place in a variety of contexts, many other factors (e.g. aim of recovery, technology options, logistical and economic feasibility, local climate, etc.) can influence the resource recovery process conditions and hence the quantity of valorization products obtained in full-scale implementation. The sheer multiplicity of technologies for the collection, transportation, treatment and valorization of various waste streams implies that the outputs can vary accordingly. The valorization efficiencies of different treatment technologies also vary and hence can influence the extent to which the CE potential is realized at full scale. While results for potential revenues are presented in this paper, they represent a linear relationship between possible prices for resource recovery products and the quantities of those products generated, and they are exclusive of information about the potential costs for establishing and operating valorization facilities. It is therefore unclear to what extent the various options in this study can be financially viable given that prices can change and costs could surpass revenues. Nevertheless, the potential revenues are relevant for determining the maximum costs allowable if a break-even point is to be reached for each respective resource recovery option (Lalander et al., 2018). This is an area for further studies, potentially building on business models described by Otoo and Drechsel (2018). In addition, it is important to keep in mind that realizing the full potential for resource recovery would require measures to address the existing social, logistical, economic, policy and governance challenges that also hinder resource recovery (Ddiba et al., 2020). 


\section{Conclusions}

This study aimed at exploring the CE valorization potential of urban organic waste streams in low- and middle-income countries, as demonstrated through the case study of Kampala, Uganda. The findings indicate that even with current rates of waste collection, there is significant potential for resource recovery from organic waste streams through products like biogas, solid fuel, insect larvae and compost. Besides contributing to energy and food security, these products can substitute traditional sources of energy, fertilizer and feed. An increase in the coverage and efficiency of waste collection services could lead to even higher valorization potential. However, potential trade-offs between resource recovery options may imply that different waste streams are directed to different valorization alternatives according to pre-determined objectives.

Realizing the full CE potential from urban organic waste streams would require addressing social, institutional, logistical and economic factors to create a basis for implementation. Detailed data on capital and operational costs of various resource recovery options would have to be established, environmental and social benefits, and trade-offs would have to be assessed, e.g. via life cycle sustainability assessment and other waste streams and valorization options which are not covered in this study could be explored. Nevertheless, the insights in this paper about resource recovery potential at city scale provide a starting step for planners and decision makers to pivot from waste treatment for disposal to waste treatment for resource recovery and hence contribute towards creating more circular and resource-efficient urban sanitation and solid waste management systems.

Supplementary Information The online version contains supplementary material available at https://doi. org/10.1007/s10668-021-01487-w.

Acknowledgements The authors are grateful to James Maiteki (NWSC) and Joel Mwesigye (KCCA) who provided some of the data from Kampala as well as colleagues at KTH Royal Institute of Technology \& the Stockholm Environment Institute (SEI) who provided feedback on draft versions of this paper, especially Göran Finnveden, Elisabeth Ekener and Caspar Trimmer. Four anonymous reviewers are also acknowledged for providing comments that significantly improved this paper. Funding for this study came from the Swedish International Development Cooperation Agency (Sida) and the Swedish Ministry of Environment through core support to SEI for the initiative on Sustainable Sanitation (www.sei.org/sustainable-sanitation) as well as the Swedish Research Council Formas through project grant number 2017-00268 to the UrbanCircle (Urban Waste into Circular Economy Benefits) project (www.sei.org/urbancircle).

Funding Open access funding provided by KTH Royal Institute of Technology.

Open Access This article is licensed under a Creative Commons Attribution 4.0 International License, which permits use, sharing, adaptation, distribution and reproduction in any medium or format, as long as you give appropriate credit to the original author(s) and the source, provide a link to the Creative Commons licence, and indicate if changes were made. The images or other third party material in this article are included in the article's Creative Commons licence, unless indicated otherwise in a credit line to the material. If material is not included in the article's Creative Commons licence and your intended use is not permitted by statutory regulation or exceeds the permitted use, you will need to obtain permission directly from the copyright holder. To view a copy of this licence, visit http://creativecommons.org/licenses/by/4.0/. 


\section{References}

Alfa, M. I., Adie, D. B., Igboro, S. B., Oranusi, U. S., Dahunsi, S. O., \& Akali, D. M. (2014). Assessment of biofertilizer quality and health implications of anaerobic digestion effluent of cow dung and chicken droppings. Renewable Energy, 63, 681-686. https://doi.org/10.1016/j.renene.2013.09.049.

Andersson, K., Rosemarin, A., Lamiozana, B., Kvarnstrom, E., McConville, J., Seidu, R., Dickin, S., Trimmer, C., (2016) Sanitation, Wastewater Management and Sustainability: from waste disposal to resource recovery, 1 st ed. United Nations Environment Programme and Stockholm Environment Institute, Nairobi and Stockholm.

Banks, I. J. (2014). To assess the impact of black soldier fly (Hermetia illucens) larvae on faecal reduction in pit latrines. $\mathrm{PhD}$ Thesis, London School of Hygiene and Tropical Medicine. https://doi.org/10. 17037/PUBS.01917781.

Bernstein, J. (2004) Social assessment and public participation in municipal solid waste management. World Bank Working Paper 463617-1202332338898

Boehm, A. B., Ismail, N. S., Sassoubre, L. M., \& Andruszkiewicz, E. A. (2017). Oceans in peril: Grand challenges in applied water quality research for the 21st century. Environmental Engineering Science, 34, 3-15. https://doi.org/10.1089/ees.2015.0252.

Boland, M. J., Rae, A. N., Vereijken, J. M., Meuwissen, M. P. M. M., Fischer, A. R. H. H., van Boekel, M. A. J. S. J. S., Rutherfurd, S. M., Gruppen, H., Moughan, P. J., \& Hendriks, W. H. (2013). The future supply of animal-derived protein for human consumption. Trends in Food Science \& Technology, 29, 62-73. https://doi.org/10.1016/j.tifs.2012.07.002.

Bond, T., \& Templeton, M. R. (2011). History and future of domestic biogas plants in the developing world. Energy for Sustainable Development, 15, 347-354. https://doi.org/10.1016/J.ESD.2011.09.003.

Breitenbeck, G. A., \& Schellinger, D. (2004). Calculating the reduction in material mass and volume during composting. Compost Science \& Utilization, 12, 365-371. https://doi.org/10.1080/10656 57X.2004.10702206.

Cofie, O., Kone, D., Rothenberger, S., Moser, D., \& Zubruegg, C. (2009). Co-composting of faecal sludge and organic solid waste for agriculture: Process dynamics. Water Research, 43, 4665-4675. https://doi.org/10.1016/J.WATRES.2009.07.021.

Danso, G. K., Otoo, M., Ekere, W., Ddungu, S., \& Madurangi, G. (2017). Market feasibility of faecal sludge and municipal solid waste-based compost as measured by farmers' willingness-to-pay for product attributes: Evidence from Kampala Uganda. Resources, 6, 31. https://doi.org/10.3390/resou rces6030031.

Ddiba, D. (2020) Exploring the circular economy of urban organic waste in sub-Saharan Africa: opportunities and challenges. Licentiate Thesis in Planning and Decision Analysis. KTH Royal Institute of Technology, Stockholm, Sweden.

Ddiba, D., Andersson, K., Koop, S. H. A., Ekener, E., Finnveden, G., \& Dickin, S. (2020). Governing the circular economy: Assessing the capacity to implement resource-oriented sanitation and waste management systems in low- and middle-income countries. Earth System Governance. https://doi. org/10.1016/j.esg.2020.100063.

UN DESA (2018). World Urbanization Prospects: the 2018 Revision-Key Facts. NY, USA: United Nations, Department of Economic and Social Affairs.

Diener, S. (2010) Valorisation of organic solid waste using the black soldier fly, Hermetia illucens, in low and middle-income countries. PhD Thesis, ETH Zurich. https://doi.org/10.3929/ethz-a-65597 79.

Diener, S., Semiyaga, S., Niwagaba, C. B., Muspratt, A. M., Gning, J. B., Mbéguéré, M., Ennin, J. E., Zurbrugg, C., \& Strande, L. (2014). A value proposition: Resource recovery from faecal sludgeCan it be the driver for improved sanitation? Resources, Conservation and Recycling, 88, 32-38. https://doi.org/10.1016/j.resconrec.2014.04.005.

Diener, S., Solano, N. M. S., Gutiérrez, F. R., Zurbrügg, C., \& Tockner, K. (2011). Biological treatment of municipal organic waste using black soldier fly larvae. Waste and Biomass Valorization, 2 , 357-363. https://doi.org/10.1007/s12649-011-9079-1.

Eghball, B., Power, J. F., Gilley, J. E., \& Doran, J. W. (1997). Nutrient, carbon, and mass loss during composting of beef cattle feedlot manure. Journal of Environmental Quality, 26, 189-193. https:// doi.org/10.2134/jeq1997.00472425002600010027x.

Ellen MacArthur Foundation, World Economic Forum, McKinsey \& Company (2013) Towards the Circular Economy Vol. 2: opportunities for the consumer goods sector. The Ellen MacArthur Foundation, World Economic Forum and McKinsey \& Company, London, United Kingdom.

Ellen MacArthur Foundation (2017) Urban Biocycles. Ellen MacArthur Foundation and the World Economic Forum, London, United Kingdom. 
Ermolaev, E., Lalander, C., \& Vinnerås, B. (2019). Greenhouse gas emissions from small-scale fly larvae composting with Hermetia illucens. Waste Management, 96, 65-74. https://doi.org/10.1016/j. wasman.2019.07.011.

Galvin, C. M. (2013) Embodied Energy and Carbon Footprint of Household Latrines in Rural Peru: The Impact of Integrating Resource Recovery. MSc Thesis, University of South Florida.

Gold, M., Ddiba, D. I. W., Seck, A., Sekigongo, P., Diene, A., Diaw, S., Niang, S., Niwagaba, C., \& Strande, L. (2017). Faecal sludge as a solid industrial fuel: a pilot-scale study. Journal of Water Sanitation and Hygiene for Development, 7, 243-251. https://doi.org/10.2166/washdev.2017.089.

Hoff, H. (2011) Understanding the nexus: Background paper for the Bonn2011 Nexus Conference: the water, energy and food security nexus. Stockholm Environment Institute (SEI), Stockholm, Sweden.

Johannesson, G. H. (1999) Sewage sludge characterization and evaluation of P availability under greenhouse conditions. MSc Thesis, The University of Guelph.

Joly, G., Nikiema, J. (2019). Global experiences on waste processing with black soldier fly (Hermetia illucens): from technology to business. International Water Management Institute (IWMI), Colombo, Sri Lanka. https://doi.org/10.5337/2019.214.

Kaza, S., Yao, L., Bhada-Tata, P., Van Woerden, F (2018). What a Waste 2.0: A Global Snapshot of Solid Waste Management to2050. World Bank Group, Washington, D.C. https://doi.org/10.1596/ 978-1-4648-1329-0.

Kinobe, J. R. (2015) Assessment of urban solid waste logistics systems: the case of Kampala, Uganda. PhD Thesis, SLU Swedish University of Agricultural Sciences.

Kirchherr, J., Reike, D., \& Hekkert, M. (2017). Conceptualizing the circular economy: An analysis of 114 definitions. Resources Conservation and Recycling, 127, 221-232. https://doi.org/10.1016/j. resconrec.2017.09.005.

Komakech, A. J. (2014) Urban waste management and the environmental impact of organic waste treatment systems in Kampala, Uganda. PhD Thesis, Department of Energy and Technology, SLU Swedish University of Agricultural Sciences.

Komilis, D., Evangelou, A., Giannakis, G., \& Lymperis, C. (2012). Revisiting the elemental composition and the calorific value of the organic fraction of municipal solid wastes. Waste Management, 32, 372 381. https://doi.org/10.1016/J.WASMAN.2011.10.034.

Lalander, C., Diener, S., Magri, M. E., Zurbrügg, C., Lindström, A., \& Vinnerås, B. (2013). Faecal sludge management with the larvae of the black soldier fly (Hermetia illucens)-From a hygiene aspect. Science of the Total Environment, 458-460, 312-318. https://doi.org/10.1016/J.SCITOTENV.2013.04. 033.

Lalander, C., Nordberg, A., \& Vinnerås, B. (2018). A comparison in product-value potential in four treatment strategies for food waste and faeces-assessing composting, fly larvae composting and anaerobic digestion. GCB Bioenergy, 10, 84-91. https://doi.org/10.1111/gcbb.12470.

Lalander, C., Senecal, J., Gros Calvo, M., Ahrens, L., Josefsson, S., Wiberg, K., \& Vinnerås, B. (2016). Fate of pharmaceuticals and pesticides in fly larvae composting. Science of the Total Environment, 565, 279-286. https://doi.org/10.1016/j.scitotenv.2016.04.147.

Liang, C., Das, K., \& McClendon, R. (2003). The influence of temperature and moisture contents regimes on the aerobic microbial activity of a biosolids composting blend. Bioresource Technology, 86, 131137. https://doi.org/10.1016/S0960-8524(02)00153-0.

Lohri, C. R., Diener, S., Zabaleta, I., Mertenat, A., \& Zurbrügg, C. (2017). Treatment technologies for urban solid biowaste to create value products: A review with focus on low-and middle-income settings. Reviews Environmental Science Biotechnology. https://doi.org/10.1007/s11157-017-9422-5.

Lu, J.-W., Zhang, S., Hai, J., \& Lei, M. (2017). Status and perspectives of municipal solid waste incineration in China: A comparison with developed regions. Waste Management, 69, 170-186. https://doi.org/10. 1016/j.wasman.2017.04.014.

Mateo-Sagasta, J., Raschid-Sally, L., Thebo, A (2015). Global wastewater and sludge production, treatment and use, in: Wastewater: Economic asset in an urbanizing world (pp. 15-38). Springer Netherlands, Dordrecht. https://doi.org/10.1007/978-94-017-9545-6_2.

McDowall, W., Geng, Y., Huang, B., Barteková, E., Bleischwitz, R., Türkeli, S., Kemp, R., \& Doménech, T. (2017). Circular economy policies in China and Europe. Journal of Industrial Ecology, 21, 651-661. https://doi.org/10.1111/jiec.12597.

MEMD, 2012. Renewable Energy Investment Guide. Ministry of Energy and Mineral Development (MEMD), Uganda, Kampala, Uganda.

Minale, M., \& Worku, T. (2014). Anaerobic co-digestion of sanitary wastewater and kitchen solid waste for biogas and fertilizer production under ambient temperature: Waste generated from condominium house. International Journal Environmental Science Technology, 11, 509-516. https://doi.org/10.1007/ s13762-013-0255-7. 
Möller, K., \& Müller, T. (2012). Effects of anaerobic digestion on digestate nutrient availability and crop growth: A review. Engineering in Life Sciences, 12, 242-257. https://doi.org/10.1002/elsc.201100085.

Moya, B., Sakrabani, R., \& Parker, A. (2019). Realizing the circular economy for sanitation: Assessing enabling conditions and barriers to the commercialization of human excreta derived fertilizer in Haiti and Kenya. Sustainability, 11, 3154. https://doi.org/10.3390/su11113154.

Müller, C (2009) Decentralised co-digestion of faecal sludge with organic solid waste, case study in Maseru, Lesotho. Swiss Federal Institute of Aquatic Science and Technology (Eawag). Dübendorf, Switzerland. Dübendorf, Switzerland.

Murray, A., Cofie, O., \& Drechsel, P. (2011). Efficiency indicators for waste-based business models: fostering private-sector participation in wastewater and faecal-sludge management. Water International, 36, 505-521. https://doi.org/10.1080/02508060.2011.594983.

Muspratt, A. M., Nakato, T., Niwagaba, C., Dione, H., Kang, J., Stupin, L., Regulinski, J., Mbéguéré, M., \& Strande, L. (2014). Fuel potential of faecal sludge: calorific value results from Uganda, Ghana and Senegal. Journal Water Sanitation Hygiene Development, 4, 223-230. https://doi.org/10.2166/washd ev.2013.055.

Nakato, T (2018) Juicy maggots earn Ssemulema cash [WWW Document]. Daily Monitor. URL https:// www.monitor.co.ug/Magazines/Farming/Juicy-maggots-earn-Ssemulema-cash--/689860-4696650k364tf/index.html. Accessed 8 June 2019.

Newton, G. L., Sheppard, D. C., Burtle, G. (2008). Black soldier fly prepupae: a compelling alternative to fish meal and fish oil. Public comment on alternative feeds for aquaculture. NOAA 15/11//2007-29/2.

Nguyen, H. C., Liang, S.-H., Li, S.-Y., Su, C.-H., Chien, C.-C., Chen, Y.-J., \& Huong, D. T. M. (2018). Direct transesterification of black soldier fly larvae (Hermetia illucens) for biodiesel production. Journal Taiwan Institute Chemical Engineers, 85, 165-169. https://doi.org/10.1016/j.jtice.2018.01.035.

Niwagaba, C. B., Otoo, M., \& Hope, L. (2018). Case: Municipal solid waste composting for cost recovery (Mbale Compost Plant, Uganda). In M. Otoo \& P. Drechsel (Eds.), Resource recovery from waste: Business models for energy, nutrients and water reuse (pp. 324-332). Routledge.

Njenga, M., Mendum, R (2018) Recovering bioenergy in Sub-Saharan Africa: gender dimensions, lessons and challenges. Colombo, Sri Lanka. https://doi.org/10.5337/2018.226.

Nkurunziza, A. G., Bateganya, N. L., Byansi, J. Z., Rokob, J., Busingye, J (2017) FSM Innovation: Leveraging FSM to Close the Urban Sanitation Loop in Kampala, in: Blackett, I., Hawkins, P. (Eds.), FSM Innovation Case Studies - Case Studies on the Business, Policy and Technology of Faecal Sludge Management. Bill \& Melinda Gates Foundation, Seattle, USA, p. 15.

Onen, H., Odong, R., \& Chemurot, M. (2019). Exploitation of locally available organic wastes for rearing black soldier fly (Hermetia illucens) larvae as a potential protein ingredient for poultry and fish feeds in Uganda. Journal Biology Nature, 10, 18-23

Otoo, M., Drechsel, P (2018) Resource recovery from waste: Business models for energy, nutrients and water reuse, 1st ed. Routledge, London. https://doi.org/10.4324/9781315780863.

Polprasert, C., \& Koottatep, T. (2017). Organic waste recycling: Technology, management and sustainability. (4th ed.). IWA Publishing, London, UK. https://doi.org/10.2166/9781780408217.

Rao, K., Hanjra, M. A., Drechsel, P., Danso, G (2015). Business models and economic approaches supporting water reuse, in: wastewater: Economic asset in an urbanizing world. Springer Netherlands, Dordrecht, pp. 195-216. https://doi.org/10.1007/978-94-017-9545-6_11.

Rose, C (2015) Developing a nutrient recovery process for recovering nutrients in anaerobic digestate in low income countries. PhD Thesis, Cranfield University.

Sauvant, D., Perez, J. M., \& Tran, G. (2004). Tables of composition and nutritional value of feed materials: pigs, poultry, cattle, sheep, goats, rabbits, horses and fish. Wageningen Academic Publishers.

Schöbitz, L., Bischoff, F., Lohri, C., Niwagaba, C., Siber, R., Strande, L., Schoebitz, L., Bischoff, F., Lohri, C. R., Niwagaba, C. B., Siber, R., \& Strande, L. (2017). GIS analysis and optimisation of faecal sludge logistics at city-wide scale in Kampala Uganda. Sustainability, 9, 194. https://doi.org/10.3390/su902 0194.

Schöbitz, L., Niwagaba, C. B., Strande, L. (2014). RRR Project - From Research to Implementation: Waste Supply and Availability in Kampala. Swiss Federal Institute of Aquatic Science and Technology (Eawag) - Department of Water and Sanitation in Developing Countries (Sandec), Dübendorf, Switzerland.

Schöbitz, L., Niwagaba, C. B., Strande, L. (2016). Shit flow diagram report for Kampala, Uganda, SFD promotion Initiative. Kampala, Uganda.

Schröder, P., Anantharaman, M., Anggraeni, K., Foxon, T. J. (2019). The Circular Economy and the Global South: Sustainable Lifestyles and Green Industrial Development, 1st ed. London, UK: Routledge. https://doi.org/10.4324/9780429434006. 
Schroeder, P., Anggraeni, K., \& Weber, U. (2018). The relevance of circular economy practices to the sustainable development goals. Journal of Industrial Ecology, 23(1), 77-95. https://doi.org/10.1111/jiec. 12732.

Schuster-Wallace, C. J., Wild, C., Metcalfe, C (2015) Valuing Human Waste as an Energy Resource: A Research Brief Assessing the Global Wealth in Waste. United Nations University-Institute for Water, Environment and Health (UNU-INWEH), Hamilton, ON, Canada.

Smith, J. U., Austin, G., Avery, L., Balana, B (2011) The potential of small-scale biogas digesters to alleviate poverty and improve long term sustainability of ecosystem services in Sub-Saharan Africa, in: Interdisciplinary Expert Workshop, Kampala (Group I) and Addis Ababa (Group II). pp. 4-5.

Sommer, S. G. (2001). Effect of composting on nutrient loss and nitrogen availability of cattle deep litter. European Journal Agronomy, 14, 123-133. https://doi.org/10.1016/S1161-0301(00)00087-3.

St-Hilaire, S., Sheppard, C., Tomberlin, J. K., Irving, S., Newton, L., McGuire, M. A., Mosley, E. E., Hardy, R. W., \& Sealey, W. (2007). Fly Prepupae as a Feedstuff for Rainbow Trout, Oncorhynchus mykiss. Journal World Aquaculture Society, 38, 59-67. https://doi.org/10.1111/j.1749-7345.2006.00073.x.

Strande, L., Ronteltap, M., \& Brdjanovic, D. (2014). Faecal sludge management: systems approach for implementation and operation (1st ed.). London: IWA Publishing.

Strande, L., Schoebitz, L., Bischoff, F., Ddiba, D., Okello, F., Englund, M., Ward, B. J., Niwagaba, C. B., Schöbitz, L., Bischoff, F., Ddiba, D., Okello, F., Englund, M., Ward, B. J., \& Niwagaba, C. B. (2018). Methods to reliably estimate faecal sludge quantities and qualities for the design of treatment technologies and management solutions. Journal Environmental Management, 223, 898-907. https://doi.org/ 10.1016/J.JENVMAN.2018.06.100.

Surendra, K. C., Tomberlin, J. K., van Huis, A., Cammack, J. A., Heckmann, L. -H. L., Khanal, S. K. (2020) Rethinking organic wastes bioconversion: Evaluating the potential of the black soldier fly (Hermetia illucens (L.)) (Diptera: Stratiomyidae) (BSF). Waste Management 117, 58-80. https://doi.org/10. 1016/j.wasman.2020.07.050.

Tchobanoglous, G., Burton, F. L., Stensel, H.D. (2003). Wastewater Engineering: Treatment and Reuse. McGraw-Hill Education, Boston, MA, USA.

Trimmer, J. T., Cusick, R. D., \& Guest, J. S. (2017). Amplifying progress toward multiple development goals through resource recovery from Sanitation. Environmental Science Technology, 51, 1076510776. https://doi.org/10.1021/acs.est.7b02147.

Tukahirwa, J. T., Lukooya, N. B. (2015). The role of policy and institutional reforms in enhancing technical efficiency of urban authorities: Reference to solid waste management in Kampala city, Uganda, in: Mohee, R., Simelane, T. (Eds.), Future Directions of Municipal Solid Waste Management in Africa. Africa Institute of South Africa, pp. 136-154.

Tyagi, V. K., \& Lo, S.-L. (2013). Sludge: A waste or renewable source for energy and resources recovery? Renewable Sustainable Energy Reviews, 25, 708-728. https://doi.org/10.1016/j.rser.2013.05.029.

Van Huis, A., Van Itterbeeck, J., Klunder, H., Mertens, E., Halloran, A., Muir, G., Vantomme, P (2013) Edible insects: future prospects for food and feed security. Food and Agriculture Organization of the United Nations.

Villarroel Walker, R., Beck, M. B. B., Hall, J. W. W., Dawson, R. J. J., \& Heidrich, O. (2014). The energywater-food nexus: Strategic analysis of technologies for transforming the urban metabolism. Journal Environmental Management, 141, 104-115. https://doi.org/10.1016/j.jenvman.2014.01.054.

Vögeli, Y., Lohri, C. R., Gallardo, A., Diener, S., Zurbrügg, C. (2014). Anaerobic digestion of biowaste in developing countries: Practical information and case studies. Department of Water and Sanitation in Developing Countries (Sandec), Swiss Federal Institute of Aquatic Science and Technology (Eawag), Dübendorf, Switzerland.

Von Sperling, M., \& de Lemos Chernicharo, C. A. (2005). Biological wastewater treatment in warm climate regions (1st ed.). London, UK: IWA Publishing.

Wang, L., Li, Y., Chen, P., Min, M., Chen, Y., Zhu, J., \& Ruan, R. R. (2010). Anaerobic digested dairy manure as a nutrient supplement for cultivation of oil-rich green microalgae Chlorella sp. Bioresource Technology, 101, 2623-2628. https://doi.org/10.1016/j.biortech.2009.10.062.

WHO, UNICEF, 2017. Progress on drinking water, sanitation and hygiene: 2017 update and SDG baselines. World Health Organization (WHO) and the United Nations Children's Fund (UNICEF), Geneva, Switzerland.

Zeller, V., Towa, E., Degrez, M., \& Achten, W. M. J. (2019). Urban waste flows and their potential for a circular economy model at city-region level. Waste Management, 83, 83-94. https://doi.org/10.1016/j. wasman.2018.10.034.

Publisher's Note Springer Nature remains neutral with regard to jurisdictional claims in published maps and institutional affiliations. 


\section{Authors and Affiliations}

\section{Daniel Ddiba ${ }^{1,2}(\mathrm{~K}) \cdot \mathrm{Kim}$ Andersson ${ }^{2} \cdot$ Arno Rosemarin $^{2}(D$. Helfrid Schulte-Herbrüggen ${ }^{1,3}$ (D) Sarah Dickin ${ }^{2}$ (D)}

Kim Andersson

kim.andersson@sei.org

Arno Rosemarin

arno.rosemarin@sei.org

Helfrid Schulte-Herbrüggen

helfrid.schulte.herbruggen@ecoloop.se

Sarah Dickin

sarah.dickin@sei.org

Department of Sustainable Development, Environmental Science and Engineering, KTH Royal Institute of Technology, Teknikringen 10B, 10044 Stockholm, Sweden

2 Stockholm Environment Institute, Linnégatan 87D, Box 24218, 10451 Stockholm, Sweden

3 Ecoloop AB, Ringvägen 100, 11860 Stockholm, Sweden 